\title{
Growth, infection and aggressiveness of Phytophthora pathogens on Rhododendron leaves
}

\author{
Clare R. Taylor ${ }^{1}$ and Niklaus J. Grünwald ${ }^{2 *}$ (i)
}

\begin{abstract}
Background: Phytophthora species are well known as important or emerging pathogens. The genus Rhododendron is of considerable importance to plant regulatory agencies because it is host to many Phytophthora species, most notably, P. ramorum and P. kernoviae. Few studies have directly contrasted the epidemiology of different Phytophthora spp. on a given host.

Methods: We investigated aspects of the foliar epidemiology (lesion size, sporulation and temperature responses) of P. cactorum, P. cambivora, P. cinnamomi, P. citrophthora, P. foliorum, P. kernoviae, P. lateralis, P. nemorosa, P. nicotianae, P. plurivora, P. ramorum and P. syringae on Rhododendron in detached leaf, whole plant chamber, and field studies.

Results: P. syringae stood out as it appeared to be a relatively weak pathogen, showing no sporulation and low levels of disease severity, except at low temperatures. P. nicotianae was consistently able to grow at higher temperatures than any of the other Phytophthora spp. and showed higher aggressiveness than any of the other species at high temperatures. P. cinnamomi and P. cactorum, typically thought of as root-infecting species, were able to cause as much foliar disease as $P$. syringae, a foliar pathogen. P. kernoviae was consistently among the most aggressive species with the highest sporulation.
\end{abstract}

Conclusion: These results provide novel insights into the comparative epidemiology of these important established and emerging Phytophthora species.

Keywords: Ecology, Epidemiology, Fitness, Ornamentals, Oomycetes

\section{Introduction}

Phytophthora species are well known as important or emerging pathogens. Notable examples include the jarrah dieback pathogen P. cinnamomi (Hardham 2005), the sudden oak death pathogen $P$. ramorum (Grünwald et al. 2008), and the potato late blight pathogen $P$. infestans (Fry 2008). P. cinnamomi threatens the jarrah tree as well as over half of the native bush land plants in Western Australia (Hardham 2005). P. ramorum is an emerging

\footnotetext{
*Correspondence: nik.grunwald@usda.gov

2 Horticultural Crops Research Laboratory, USDA ARS, Corvallis, OR 97330, USA
}

Full list of author information is available at the end of the article exotic pathogen of oaks and many other woody ornamental hosts in the forests of the Western US and larch in Europe (Grünwald et al. 2008, 2012; Brasier and Webber 2010). P. infestans is the pathogen of potato which led to the Great Famine in Ireland, and this pathogen continues to have an impact on potato production to this day (Fry 2008; Fry et al. 2015). Some plants are host to multiple Phytophthora spp., thus increasing the probability of inadvertently becoming vectors for the movement of novel species.

Transport of ornamental plants is likely a major route for the movement of Phytophthora species (Scott et al. 2019; Barwell et al. 2021; Liebhold et al. 2012; Brasier 2008; Jung et al. 2016). Movement of pathogens could 
occur on asymptomatic plants or with pathogen propagules in potting media. This is thought to have been the case with the import of ornamental plants such as Rhododendron, Pieris, Viburnum, and Camellia into the USA, and hypothesized to be involved in the introduction of P. ramorum into California (Mascheretti et al. 2008), the Pacific Northwest (Goss et al. 2009, 2011), and Europe (Van Poucke et al. 2012).

Rhododendron plants are hosts to many Phytophthora spp. (Jones and Benson 2001) further exacerbating the potential for vectoring new invasions. Phytophthora spp. infecting Rhododendron are typically characterized as causing root rot, shoot dieback or foliar blight: Typical root rotting Phytophthora spp. include P. cactorum, $P$. cambivora, $P$. cinnamomi, $P$. cryptogea, $P$. gonapodyides, $P$. heveae, $P$. lateralis, $P$. megasperma, $P$. nicotianae, and P. plurivora (formerly P. citricola) (Jones and Benson 2001; Parke et al. 2014); species typically causing dieback or foliar blight symptoms include $P$. cactorum, $P$. heveae, $P$. kernoviae, $P$. nicotianae, $P$. plurivora, $P$. ramorum and P. syringae (Brasier et al. 2005; Jones and Benson 2001; Werres et al. 2001; Parke et al. 2014; Knaus et al. 2015). The ability to infect roots and or foliage is not mutually exclusive. Some species are able to infect both roots and foliage while others are more or less specialized to either foliage or roots (Jones and Benson 2001). The effort described herein measures foliar disease development but includes both root and foliar Phytophthora pathogens of Rhododendron.

The genus Rhododendron is of considerable importance to plant regulatory agencies because it is host to many Phytophthora species, most notably, $P$. ramorum and $P$. kernoviae (Brasier et al. 2005; Werres et al. 2001; Grünwald et al. 2008). We currently know very little about the epidemiology of different Phytophthora diseases on Rhododendron, which is an important crop in the nursery industry. Rhododendron is known to host at least a dozen Phytophthora spp. (Erwin and Ribeiro 1996; Hoitink and Schmitthenner 1974; Parke et al. 2014; Knaus et al. 2015), yet no study exists that has compared these Phytophthora spp. on Rhododendron in a systematic effort. Understanding the epidemiology of each Phytophthora species will contribute to the design of more targeted disease management strategies as well as inform regulatory agencies on the risks associated with both Rhododendron plants and particular Phytophthora spp. associated with Rhododendron (Parke and Grünwald 2012).

Few studies have directly contrasted the epidemiology of different Phytophthora spp. on a given host (Jeger and Pautasso 2008; Wilcox and Mircetich 1985). Pathogens can be compared based on measures of fitness or aggressiveness. Typical variables assessed for Phytophthora spp. include infection rate, severity measured as proportion (or percent) of the area of a plant or plant part affected by disease, or as an actual measure of the area diseased, or area under the lesion expansion curve (AULEC), and sporulation (Kato et al. 1997; Lebreton et al. 1999; Spielman et al. 1992).

We studied aggressiveness on Rhododendron and the response of Phytophthora species to temperature. We tested two specific hypotheses: First, there are significant differences in aggressiveness among different Phytophthora spp. infecting Rhododendron. Second, the temperature range for disease development varies among Phytophthora spp. Where possible, isolates were evaluated in detached leaf, whole plant, and field studies but some of the species were subject to quarantines and could not be evaluated in the field. Understanding the temperature requirements and aggressiveness of these Phytophthora species to Rhododendron will help improve disease management enabling growers to adapt agricultural practices to target different Phytophthora species at different temperatures (Parke and Grünwald 2012). Cardinal temperatures could also be used as indicators during plant health inspection in nurseries.

\section{Materials and methods}

\section{Species and isolates}

The Phytophthora species used in this study were $P$. cactorum, $P$. cambivora, P. cinnamomi, $P$. citrophthora, $P$. foliorum, $P$. kernoviae, $P$. lateralis, $P$. nemorosa, $P$. nicotianae, $P$. plurivora, $P$. ramorum and $P$. syringae (Table 1 ). Isolates were maintained at $20{ }^{\circ} \mathrm{C}$ in the dark on $10 \% \mathrm{~V} 8$ agar (100 ml V8 juice; $2 \mathrm{~g} \mathrm{CaCO}_{3} ; 30 \mathrm{mg} / \mathrm{L} \beta$-sitosterol (EMD Chemicals, Inc., San Diego, CA); 15 g agar; $900 \mathrm{ml}$ deionized water) in Petri plates and transferred monthly. Isolates were identified to species by sequencing of the internal transcribed spacer (ITS) region as described by Grünwald et al. (2011). PCR amplicons of the ITS region were sequenced in forward and reverse at the Center for Genome Research and Biocomputing (CGRB, Oregon State University, Corvallis) on an ABI 3730 capillary sequencer using standard reagents (Applied Biosystems Inc.). Species were identified by BLAST search using Phytophthora-ID.org (Grünwald et al. 2011).

\section{Plant maintenance}

The highly susceptible Rhododendron 'Catawbiense Boursault' (CB) and the moderately susceptible Rhododendron 'Lee's Dark Purple' (LDP) (McDonald and Grünwald, unpublished) were maintained in \#1 trade gallon containers of 'Professional Growing Mix' (Sun Gro Horticulture Canada Ltd., Vancouver, British Columbia) in a greenhouse with natural lighting and watered as needed. The plants were fertilized every 2 months with slow release pellets of 'Apex 20-10-10/20-4.3-8.3 Evergreen Nursery 
Table 1 Phytophthora species and isolates used in this study

\begin{tabular}{|c|c|c|c|c|}
\hline Species & Isolate ID & $\begin{array}{l}\text { Host genus or environment of } \\
\text { origin }\end{array}$ & Origin & Isolated by \\
\hline P. cactorum & PCC-07-001* & Fragaria & OR & P. Reeser ${ }^{1}$ \\
\hline P. cactorum & PCC-07-003 & Panax & OR & P. Reeser ${ }^{1}$ \\
\hline P. cactorum & PCC-07-004 & Fragaria & OR & P. Reeser ${ }^{1}$ \\
\hline P. cambivora & PCM-07-001* & Fagus & OR & P. Reeser ${ }^{1}$ \\
\hline P. cambivora & PCM-07-002 & Photinia & OR & P. Reeser ${ }^{1}$ \\
\hline P. cambivora & PCM-07-003 & Ulmus & OR & P. Reeser ${ }^{1}$ \\
\hline P. cinnamomi & PCN-07-002* & Vaccinium & OR & P. Reeser ${ }^{1}$ \\
\hline P. cinnamomi & JP-06-0006 & Pinus & OR & J. Parke $^{2} /$ N. Grünwald \\
\hline P. cinnamomi & JP-06-0217 & soil/substrate & OR & J. Parke $^{2} /$ N. Grünwald \\
\hline P. citrophthora & PCR-07-001 & Picea & OR & P. Reeser ${ }^{1}$ \\
\hline P. citrophthora & PCR-07-003 & Rhododendron & OR & P. Reeser ${ }^{1}$ \\
\hline P. citrophthora & PCR-07-005* & Pieris & OR & P. Reeser ${ }^{1}$ \\
\hline P. foliorum ${ }^{\dagger}$ & JP-08-070 & Pieris & OR & J. Parke $2 /$ N. Grünwald \\
\hline P. foliorum ${ }^{\dagger}$ & P-04-001* & azalea & TN & K. Lamour ${ }^{4}$ \\
\hline P. kernoviae ${ }^{\dagger}$ & PK-05-001 & unknown & UK & C. Brasier ${ }^{5}$ \\
\hline P. kernoviae ${ }^{\dagger}$ & PH-05-005 & Annona & $\mathrm{NZ}$ & M. Coffey ${ }^{6}$ \\
\hline P. kernoviae ${ }^{\dagger}$ & PK-05-002* & unknown & UK & C. Brasier ${ }^{5}$ \\
\hline P. lateralis ${ }^{\dagger}$ & PL-0X-001 & unknown & CA & E. Hansen ${ }^{1}$ \\
\hline P. lateralis ${ }^{\dagger}$ & PL-05-004 & Chamaecyparis & OR & M. Garbelotto ${ }^{7}$ \\
\hline P. lateralis ${ }^{\dagger}$ & PL-06-009 & Chamaecyparis & WA & E. Hansen ${ }^{1}$ \\
\hline P. lateralis ${ }^{\dagger}$ & PL-06-003* & Chamaecyparis & CAN & E. Hansen ${ }^{1}$ \\
\hline P. nemorosa ${ }^{\dagger}$ & PN-07-002 & Lithocarpus & OR & E. Hansen ${ }^{1}$ \\
\hline P. nemorosa ${ }^{\dagger}$ & P-07-034 & Camellia & OR & J. Parke ${ }^{2}$ N. Grünwald \\
\hline P. nemorosa ${ }^{\dagger}$ & P-06-010* & Pieris & OR & N. Osterbauer \\
\hline P. nicotianae & PNI-07-001 & Forsythia & OR & P. Reeser ${ }^{1}$ \\
\hline P. nicotianae & PNI-07-002* & Malva & OR & P. Reeser ${ }^{1}$ \\
\hline P. nicotianae & PNI-07-005 & Daphne & OR & P. Reeser ${ }^{1}$ \\
\hline P. plurivora & PCT-07-002* & nursery & OR & P. Reeser ${ }^{1}$ \\
\hline P. plurivora & JP-07-0251 & Kalmia & OR & J. Parke $2 /$ N. Grünwald \\
\hline P. plurivora & $J P-06-0160$ & soil/substrate & OR & J. Parke 2 NN. Grünwald \\
\hline P. ramorum ${ }^{+}$ & PR-05-186 & Rhododendron & OR & N. Osterbauer ${ }^{8}$ \\
\hline P. ramorum ${ }^{\dagger}$ & PR-07-113 & Rhododendron & OR & N. Osterbauer ${ }^{8}$ \\
\hline P. ramorum ${ }^{+}$ & PR-07-166* & Rhododendron & OR & J. Ristaino ${ }^{9}$ \\
\hline P. syringae & PSY-07-001 & Malus & OR & P. Reeser ${ }^{1}$ \\
\hline P. syringae & PSY-07-002* & Zelkova & OR & P. Reeser ${ }^{1}$ \\
\hline P. syringae & PSY-07-003 & Pyrus & OR & P. Reeser ${ }^{1}$ \\
\hline
\end{tabular}

* denotes isolates used in the temperature detached leaf inoculation experiment

${ }^{\dagger}$ denotes species evaluated in containment in compliance with active USDA APHIS PPQ permits

${ }^{1}$ Department of Botany and Plant Pathology, Oregon State University

${ }^{2}$ Department of Crop and Soil Science, Oregon State University

${ }^{3}$ USDA ARS HCRL, Corvallis, OR

${ }^{4}$ Department of Entomology and Plant Pathology, The University of Tennessee

${ }^{5}$ Forestry Commission, Forest Research Station, Farnham, Surrey, UK

${ }^{6}$ The College of Natural and Agricultural Sciences, UC Riverside

${ }^{7}$ Department of ESPM, UC Berkley

${ }^{8}$ Oregon Department of Agriculture, Salem, OR

${ }^{9}$ Department of Plant Pathology, NC State University

CA California, USA; CAN Canada; NZ New Zealand; OR Oregon, USA; TN Tennessee, USA; UK United Kingdom; WA Washington, USA 
Fertilizer' (J. R. Simplot, Boise, ID) and twice a year with a foliar application of 'Liquid Iron' (Voluntary Purchasing Groups Inc., Bonham, TX).

\section{Inoculum production}

Petri plates with $10 \mathrm{ml}$ of $10 \%$ V8 juice broth were inoculated with three $0.5 \mathrm{~cm}$ diameter mycelial plugs of a Phytophthora isolate. Broth plates were incubated for 4 days in the dark at $20{ }^{\circ} \mathrm{C}$. The broth was then decanted gently without dislodging the mycelial mats and replaced with $10 \mathrm{ml}$ of either sterile distilled water, filter sterilized pond water or non-sterile filtered soil extract to create starvation conditions and stimulate sporangia production (Ahonsi et al. 2007). The plates were then incubated in the dark at $20{ }^{\circ} \mathrm{C}$ for three days. Zoospore release was induced by incubating plates at $4{ }^{\circ} \mathrm{C}$ for one hour and then placing them at room temperature on the lab bench for one hour. The concentration of zoospores was estimated using a haemocytometer and adjusted to the desired concentration by adding deionized $\mathrm{H}_{2} \mathrm{O}$.

\section{Epidemiological measurement}

Pathogens can be compared based on measures of fitness or aggressiveness (Kato et al. 1997; Tooley et al. 1986; Harris et al. 2021). Here aggressiveness was determined by assessing intensity of disease, where intensity includes infection rate, severity, and sporulation caused by Phytophthora spp. on Rhododendron. Infection rate is defined here as the number of successful infections given a certain inoculum concentration. Severity is defined as a measure of the intensity of disease measured either as the proportion (or percent) of the area of a plant or plant part affected by disease, or as an actual measure of the area diseased, or area under the lesion expansion curve (AULEC). Sporulation was assessed as the number of sporangia produced per unit lesion area. Pathogen response to temperature was quantified as the radial growth rates of colonies on agar plates or of lesions on leaves determined at different temperatures.

\section{Aggressiveness and sporulation: detached leaf experiments}

Disease severity and sporulation were assessed in detached leaf assays using all isolates including quarantine and non-quarantine isolates (Table 1). Experiments followed a factorial $12 \times 2$ (species $\times$ cultivar) randomized complete block design with six replications and ten subsamples (individual leaves) per replicate. There were only two isolates of $P$. foliorum available, and there were four isolates of $P$. lateralis used. Three isolates were used in mixture for all other species (Table 1). A replication consisted of ten leaves of a cultivar inoculated with a species (isolates mixed per Table 1). Leaves were detached from Rhododendron plants and placed in clear plastic boxes $(23 \times 33 \times 11.5 \mathrm{~cm})$ on a plastic mesh over moist vermiculite. Leaves were wound inoculated by abrading a point in the center of each leaf to one side of the mid-vein with a sterile hypodermic needle and then placing $20 \mu \mathrm{l}$ of zoospore solution $\left(5 \times 10^{3}\right.$ zoospores $\mathrm{ml}^{-1}$ ) onto the wound. A fine mist of sterile water was applied immediately after inoculation and every $48 \mathrm{~h}$ thereafter and leaves were incubated at $18{ }^{\circ} \mathrm{C}$ with a $16 \mathrm{~h}$ day length. After 10 days, leaves were photographed and photographs were digitally processed for lesion area using Assess (version 2.0, APS Press, St. Paul, MN). The leaves from each experimental unit having developed lesions were then placed together in a $50 \mathrm{ml}$ tube with $20 \mathrm{ml} \mathrm{CuSO}_{4}$, vortexed to dislodge the sporangia, and centrifuged at $290 \times g(1,200 \mathrm{rpm})$ for $5 \mathrm{~min}$. Pellets were re-suspended in $100 \mu \mathrm{l}$ of $\mathrm{CuSO}_{4}$ and the number of sporangia was estimated using a hemacytometer. This experiment was conducted twice.

Aggressiveness and sporulation: whole plant experiments Disease severity, incidence and sporulation of eight Phytophthora species were assessed on whole plants without wounding. Only eight species yielded enough zoospore inoculum to inoculate the whole plants. This experiment was conducted twice with six replicates each. An experimental unit consisted of a single plant. Small $(10 \mathrm{~cm}$ container $/ 570 \mathrm{ml}$ ) Rhododendron cv. catawbiense 'Boursault' plants were dip-inoculated in zoospore suspension at a concentration of $3 \times 10^{3}$ zoospores $\mathrm{ml}^{-1}$ for $10 \mathrm{~min}$. The plants were then wrapped in plastic bags to maintain humidity and leaf wetness and incubated at $18{ }^{\circ} \mathrm{C}$ with a $16 \mathrm{~h}$ day length for 7 days. The leaves were then removed, and lesion area was estimated as described above. Three infected leaves were selected from each plant to assess sporulation of the lesions as described above.

\section{Effect of temperature: detached leaf and agar culture experiments}

The effect of temperature on colony and lesion growth rates was investigated. One isolate per species was inoculated on detached leaves (Table 1) as previously described and all isolates per species (Table 1) were evaluated on agar plates and placed in growth chambers randomly assigned to temperatures at $5{ }^{\circ} \mathrm{C}$ increments from $5{ }^{\circ} \mathrm{C}$ to $35{ }^{\circ} \mathrm{C}$ with a $16 \mathrm{~h}$ day length. Experiments followed a factorial $7 \times 7$ (temperature $\times$ species) randomized complete block design with five replicates per experiment. An experimental unit consisted of a single detached leaf or Petri plate. Detached Rhododendron cv. catawbiense 'Boursault' leaves were placed in moist tubs and wound inoculated with a single mycelial plug. Petri plates of $10 \%$ V8 agar were inoculated using a mycelial plug taken from 
the Petri plates the species were maintained on. Two perpendicular measurements (length and width) of lesion or colony diameter were taken using calipers every other day for 12 days. Lesion area was estimated using the average of these two measurements to represent the diameter of a circle and area was then calculated as colony area $=\pi r^{2}$ where $r=$ radius. Experiments were conducted three times and temperature treatments were randomized among chambers between experiments. P. nicotianae and $P$. syringae were included as positive controls in both the quarantine (P. foliorum, P. kernoviae, P. lateralis, $P$. nemorosa, $P$. ramorum) and non-quarantine species (P. cactorum, P. cambivora, P. cinnamomi, P. citrophthora, $P$. nicotianae, $P$. plurivora, and $P$. syringae) experiments (Table 1). Actual temperature was measured using HOBO RH Temp Light External Sensor Logger H09-00402 (Onset Computer Corporation, Pocasset, MA).

\section{Aggressiveness and effect of temperature: field experiments}

To assess the effect of environmental temperature variation on Phytophthora epidemics whole plants of both Rhododendron cultivars in \#1 trade gallon containers were wound inoculated with a mixture of strains (Table 1) in a nursery like setting. A factorial $7 \times 2$ (species $\times$ cultivar) randomized complete block design was used with six replicates. The experiment was conducted four times, roughly every three to four months of the year. The plants were inoculated on three leaves (sub-samples) by wounding each leaf (as above) and clipping an Corning cryogenic vial cap (No. 430659) containing three agar plugs (one plug for each isolate of the same Phytophthora species) and a drop of water to the leaf (Table 1). Sterile agar plugs were used on control plants. The plants were inoculated in a greenhouse and kept there for one week for infection to take place, after which inoculum caps were removed and the plants were moved to the field for lesion development for a period of six weeks. During that time, two perpendicular measurements of lesions were taken using calipers each week, and this was used to estimate lesion area (as described above). Area under the lesion expansion curve (AULEC) in $\mathrm{mm}^{2} \times$ days was calculated from these measurements using the trapezoid method
(Sparks et al. 2008). Lesions were destructively sampled six weeks after inoculation and the Phytophthora species were re-isolated from the lesion margin onto V8 PARP agar to confirm identity of the re-isolated strain by morphology on V8 10\% agar. Weather data was collected using a Campbell Scientific CR1000 data logger with sensors recording the temperature (CR500). The mean temperature over the six weeks of each experiment was calculated using hourly temperature recordings from the data logger. Supplemental overhead irrigation was applied for $15 \mathrm{~min}$, six times a day during experiments 1 and 2 , which occurred during the dry season to maintain conditions conducive to epidemic development.

\section{Statistical analysis}

Lesion area $\left(\mathrm{mm}^{2}\right), \%$ lesion area, the area under the lesion expansion curve (AULEC, $\mathrm{mm}^{2} \times$ days), and sporulation (sporangia $/ \mathrm{mm}^{2}$ lesion area) were subjected to analysis of variance. Sporulation, \% lesion area and AULEC (field experiments) were square-root transformed for homogeneity of variance and to normalize the data. A log transformation was used for \% lesion area from the field experiments and for AULEC from growth chamber temperature experiments for homogeneity of variance and to normalize the data. Analyses of variance using the general mixed linear model and mean separation using Tukey's test were conducted using Minitab (State College, PA) (Tukey 1991). Fixed effects were Rhododendron cultivar, Phytophthora species and where applicable, temperature; replicate was considered a random effect.

\section{Results}

\section{Aggressiveness and sporulation: detached leaf} experiments

We evaluated aggressiveness of each Phytophthora species on detached Rhododendron leaf assays for lesion area and sporulation. The three species with significantly higher \% lesion area were P. nicotianae, $P$. ramorum, and $P$. foliorum in both experiments $(\mathrm{P}<0.01)$, although they were not ranked in the same order on both cultivars (Fig. 1, A, C, E and G). Sporulation per $\mathrm{mm}^{2}$ lesion area in both experiments was higher for P. kernoviae than any

\section{(See figure on next page.)}

Fig. 1 Detached leaf inoculation of twelve Phytophthora species. A, and E, show lesion area (\%) on Rhododendron cv. catawbiense'Boursault' in experiments 1 and 2, respectively. B and $\mathbf{F}$ show sporulation (sporangia/ $\mathrm{mm}^{2}$ ) on Rhododendron cv. catawbiense'Boursault' in experiments 1 and 2, respectively. C, and G, show lesion area (\%) on Rhododendron cv. 'Lee's dark purple' in experiments 1 and 2, respectively. $\mathbf{D}$ and $\mathbf{H}$ show sporulation (sporangia/mm²) on Rhododendron cv. 'Lee's dark purple' in experiments 1 and 2, respectively. Lower case letters in each panel represent statistically significant differences among Phytophthora spp. within each cultivar based on Tukey's test at the $95 \%$ confidence level carried out on square root transformed data. The data presented are not transformed. Bars show standard deviation from the mean of replicates (based on non-transformed data) 


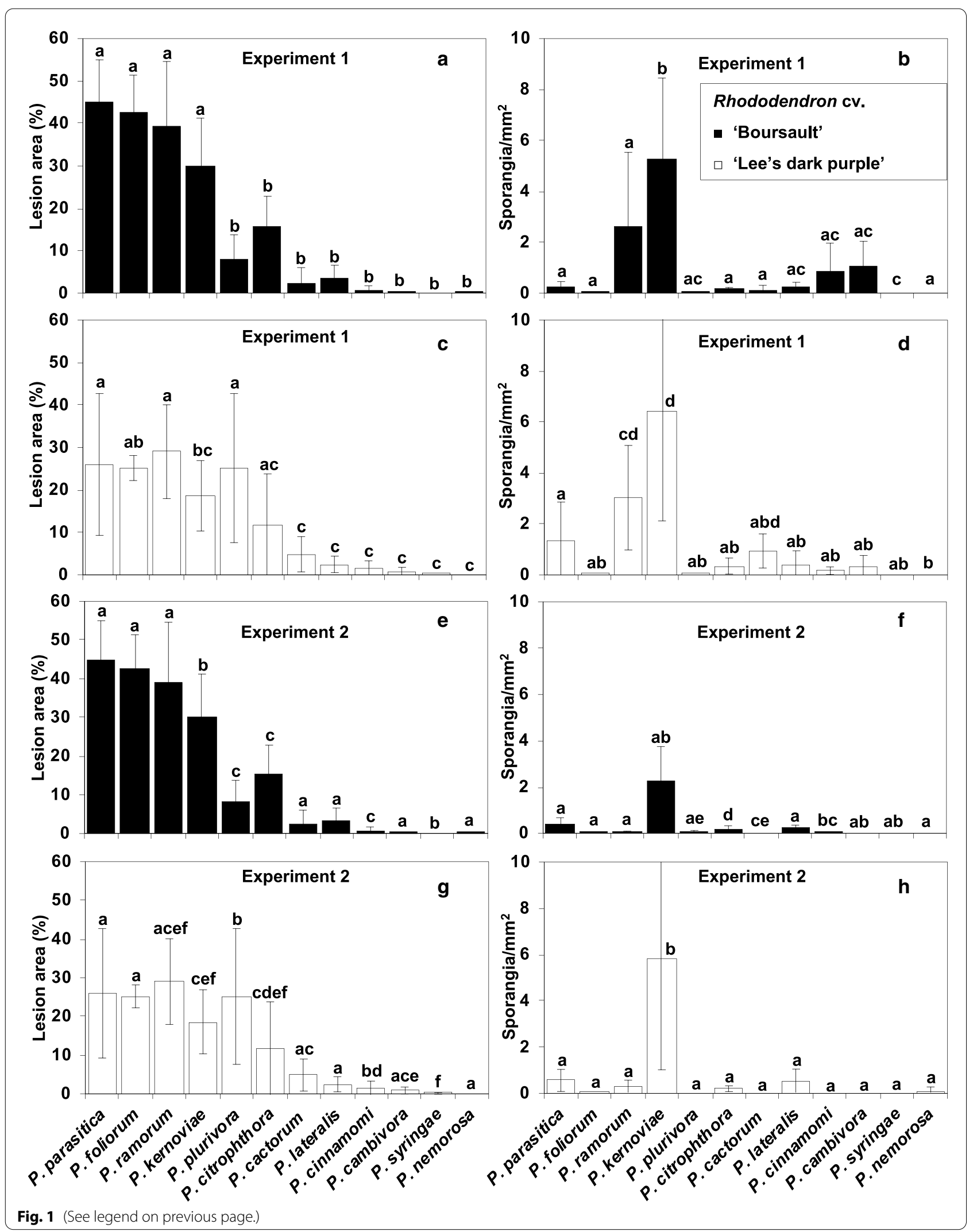


Table 2 Analysis of variance of lesion area and sporulation for detached leaf inoculation of twelve Phytophthora species

\begin{tabular}{|c|c|c|c|c|}
\hline Experiment; effect & Source & DF & $\mathbf{F}$ & $P$ \\
\hline \multirow[t]{4}{*}{ Experiment $1 ; \%$ lesion area $^{\dagger}$} & Species & 11 & 121.99 & $<0.001$ \\
\hline & Cultivar & 1 & 7.97 & 0.005 \\
\hline & Species*Cultivar & 11 & 8.11 & $<0.001$ \\
\hline & Block & 4 & 0.50 & 0.733 \\
\hline \multirow[t]{2}{*}{ Experiment 1; \% lesion area on Rhododendron cv. CB } & Species & 11 & 30.46 & $<0.001$ \\
\hline & Block & 4 & 0.69 & 0.606 \\
\hline \multirow[t]{2}{*}{ Experiment 1; \% lesion area on Rhododendron cv. LDP } & Species & 11 & 8.54 & $<0.001$ \\
\hline & Block & 4 & 0.75 & 0.566 \\
\hline \multirow[t]{4}{*}{ Experiment 1 ; sporulation $/ \mathrm{mm}^{2 \dagger}$} & Species & 11 & 23.67 & $<0.001$ \\
\hline & Cultivar & 1 & 1.07 & 0.303 \\
\hline & Species*Cultivar & 11 & 1.10 & 0.373 \\
\hline & Block & 4 & 0.17 & 0.953 \\
\hline \multirow[t]{2}{*}{ Experiment 1 ; sporulation $/ \mathrm{mm}^{2+}$ on Rhododendron $\mathrm{Cv} . \mathrm{CB}$} & Species & 11 & 10.60 & $<0.001$ \\
\hline & Block & 4 & 0.46 & 0.766 \\
\hline \multirow[t]{2}{*}{ Experiment 1 ; sporulation $/ \mathrm{mm}^{2 \dagger}$ on Rhododendron cv. LDP } & Species & 11 & 14.05 & $<0.001$ \\
\hline & Block & 4 & 0.55 & 0.701 \\
\hline \multirow[t]{4}{*}{ Experiment 2; \% lesion area $^{\dagger}$} & Species & 11 & 163.69 & $<0.001$ \\
\hline & Cultivar & 1 & 70.48 & $<0.001$ \\
\hline & Species*Cultivar & 11 & 8.20 & $<0.001$ \\
\hline & Block & 4 & 0.05 & 0.996 \\
\hline \multirow[t]{2}{*}{ Experiment 2; \% lesion area on Rhododendron cv. CB } & Species & 11 & 76.55 & $<0.001$ \\
\hline & Block & 4 & 0.43 & 0.785 \\
\hline \multirow[t]{2}{*}{ Experiment 2; \% lesion area on Rhododendron cv. LDP } & Species & 11 & 23.76 & $<0.001$ \\
\hline & Block & 4 & 0.57 & 0.686 \\
\hline \multirow[t]{4}{*}{ Experiment 2; sporulation $/ \mathrm{mm}^{2 \dagger}$} & Species & 11 & 38.47 & $<0.001$ \\
\hline & Cultivar & 1 & 4.94 & 0.029 \\
\hline & Species*Cultivar & 11 & 1.90 & 0.050 \\
\hline & Block & 4 & 3.36 & 0.013 \\
\hline \multirow[t]{2}{*}{ Experiment 2; sporulation $/ \mathrm{mm}^{2 \dagger}$ on Rhododendron Cv. CB } & Species & 11 & 27.17 & $<0.001$ \\
\hline & Block & 4 & 1.39 & 0.253 \\
\hline \multirow[t]{2}{*}{ Experiment 2; sporulation $/ \mathrm{mm}^{2 \dagger}$ on Rhododendron cv. LDP } & Species & 11 & 20.04 & $<0.001$ \\
\hline & Block & 4 & 3.82 & 0.009 \\
\hline
\end{tabular}

$\mathrm{CB}=$ Rhododendron cv. catawbiense 'Boursault'; $\mathrm{LDP}=$ Rhododendron cv. 'Lee's dark purple'. Bold $P$ values are significant at $<0.05$

${ }^{\dagger}$ Data were square root transformed for analysis of variance

of the other species (Fig. 1, B, D, F and H). There was a significant species $\times$ cultivar interaction for lesion area $\left(\mathrm{mm}^{2}\right)$ and \% lesion area $(\mathrm{P}<0.001)$; however, there was no significant species $\times$ cultivar interaction for sporulation (Table 2). Some species high lesion area had low sporulation (P. nicotianae, P. foliorum); P. kernoviae persistently had high sporulation and high lesion area compared to the other species evaluated.

Aggressiveness and sporulation: whole plant experiments We evaluated aggressiveness of each Phytophthora species on whole Rhododendron plants for lesion area and sporulation in a containment growth chamber. Of the twelve Phytophthora species studied, only eight yielded sufficient concentrations of zoospores to carry out whole plant dip inoculation experiments. P. foliorum, $P$. nemorosa, $P$. cambivora and $P$. cinnamomi either failed to produce sporangia in culture or did not release zoospores in sufficient concentrations to be used in these experiments. In both experiments there was a significant difference in the percentage of leaves infected per plant among the eight species $(P<0.001)$ with $P$. ramorum, $P$. kernoviae and $P$. citrophthora exhibiting the highest infection rate (Fig. 2, A, B). There were significant differences in lesion area (\%) among the Phytophthora species tested $(P \leq 0.002)$ (Fig. 2, C, D). P. ramorum, P. kernoviae, P. citrophthora, $P$. nicotianae and $P$. cactorum showed comparable levels of sporulation (Fig. 2, E, F). P. plurivora, 

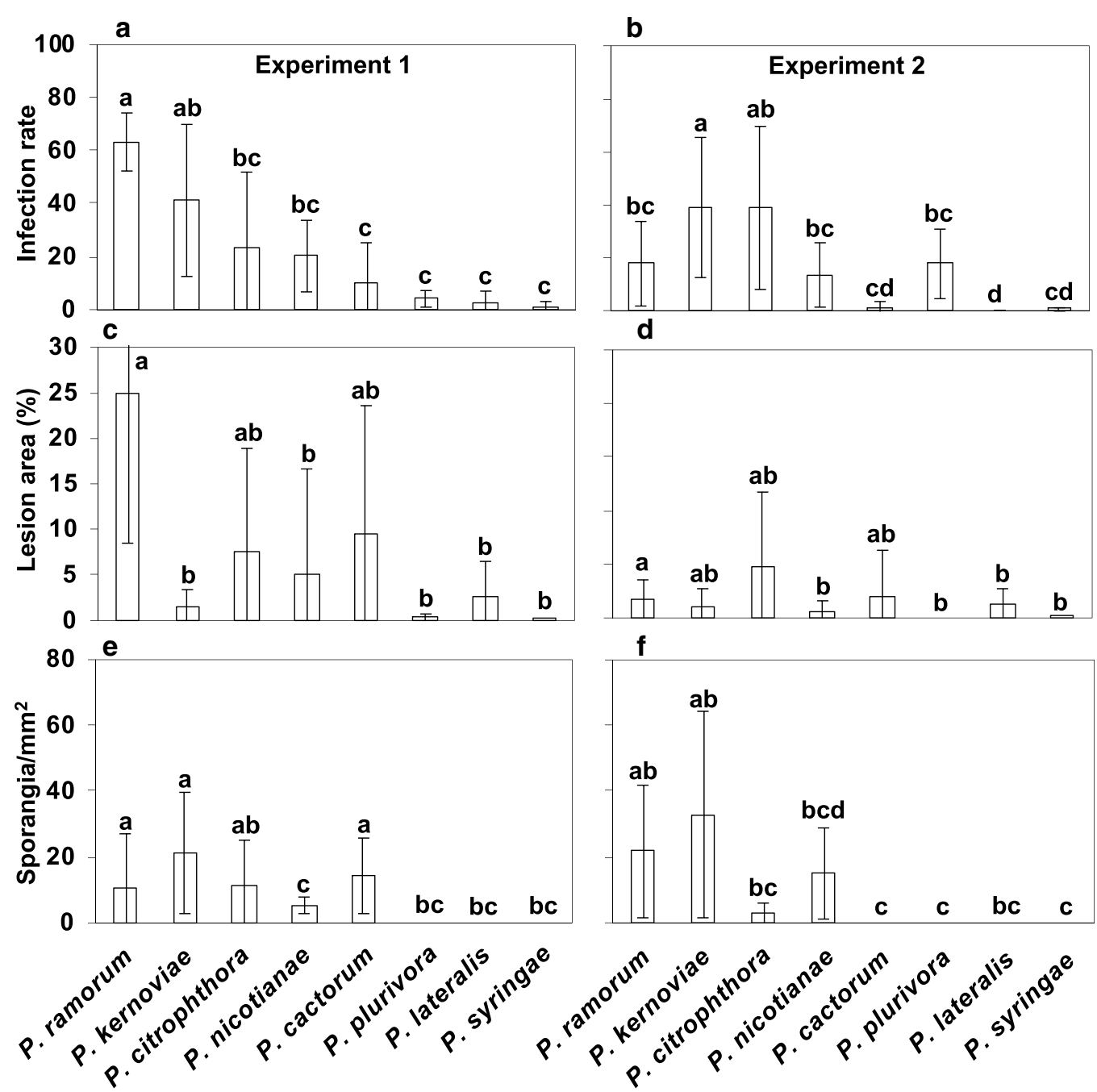

Fig. 2 A, B, Percentage of leaves infected at $18{ }^{\circ} \mathrm{C}$ (\% of leaves infected), C, D, lesion area (\%), and $\mathbf{E}$, F, sporulation (sporangia/mm ${ }^{2}$ ), on non-wounded dip-inoculated Rhododendron cv. catawbiense'Boursault' plants in experiments 1 and 2, respectively. Bars show standard deviation from the mean of replicates (non-transformed data). Lower case letters in each panel represent statistically significant differences based on Tukey's test at the 95\% confidence level (based on transformed data)

P. lateralis, and $P$. syringae did not sporulate under these conditions (Fig. 2, E, F).

\section{Effect of temperature: detached leaf and agar culture experiments}

We evaluated the effect of temperature on radial growth of Phytophthora spp. in vitro in controlled growthchamber experiments on detached leaves and in agar culture. There was a significant species $\times$ temperature interaction for colony growth rate, lesion growth rate and AULEC in all experiments $(P<0.001)$ (Fig. 3, 4). Three independent experiments showed similar trends for the colony growth rate response of Phytophthora spp. to different temperatures (Fig. 3). Notably, $P$. cambivora, $P$. cinnamomi, $P$. citrophthora and $P$. nicotianae had similar responses to temperature with the ability to grow at $30{ }^{\circ} \mathrm{C}$ (Fig. 3). P. nicotianae stood out with the ability to grow well at high temperatures and is the only species that could grow at or potentially above $35{ }^{\circ} \mathrm{C}$. Similarly, P. syringae, $P$. kernoviae, P. lateralis, $P$. nemorosa, and $P$. ramorum, stood out as requiring lower temperatures for growth and their inability to grow at $\geq 30{ }^{\circ} \mathrm{C}$ (Fig. 3).

Detached leaf inoculations with seven (non-quarantine) Phytophthora spp. showed patterns similar to the Petri dish assays (Fig. 4). P. nicotianae, P. plurivora and $P$. citrophthora all had significantly higher AULEC than the other four species across all temperatures in 


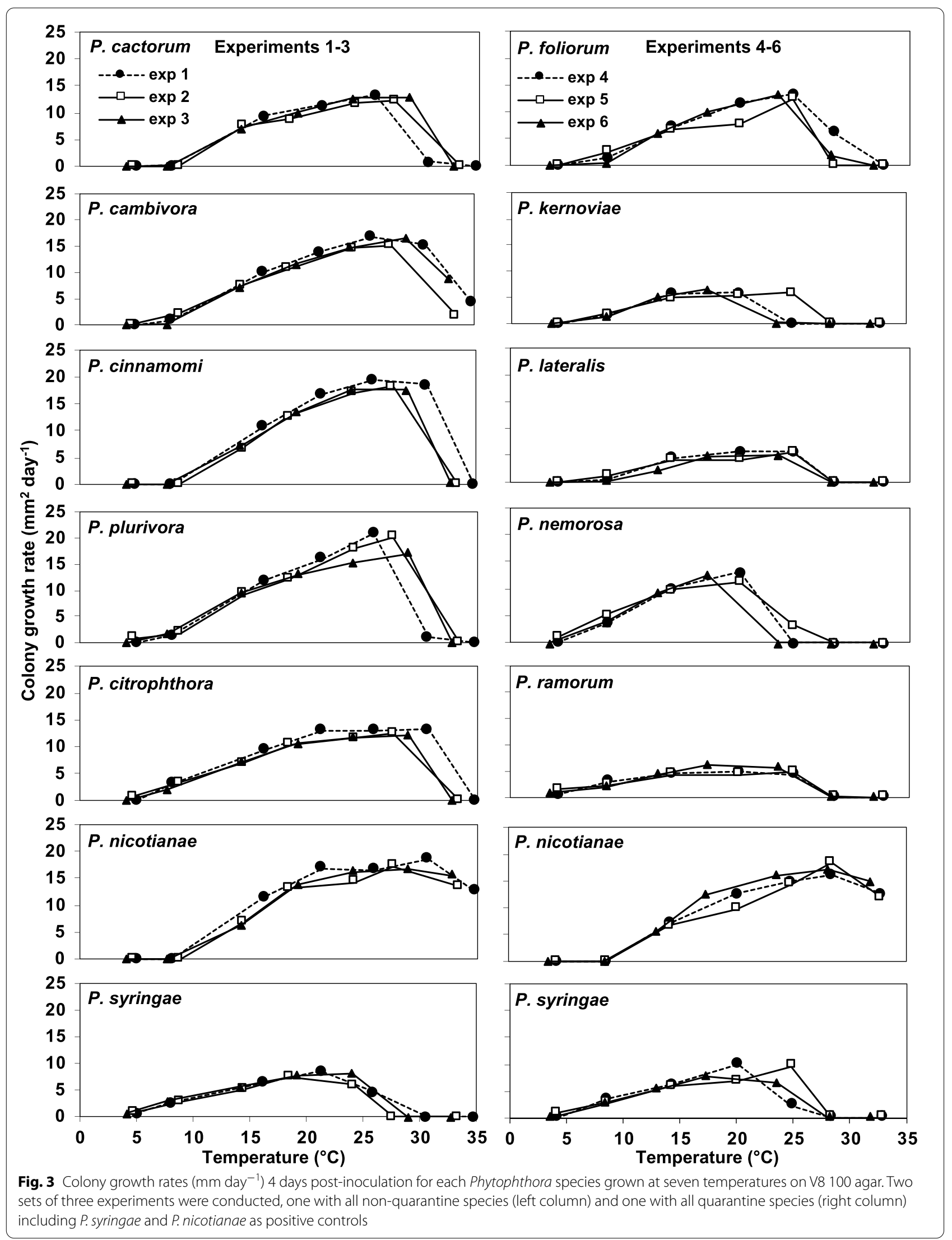




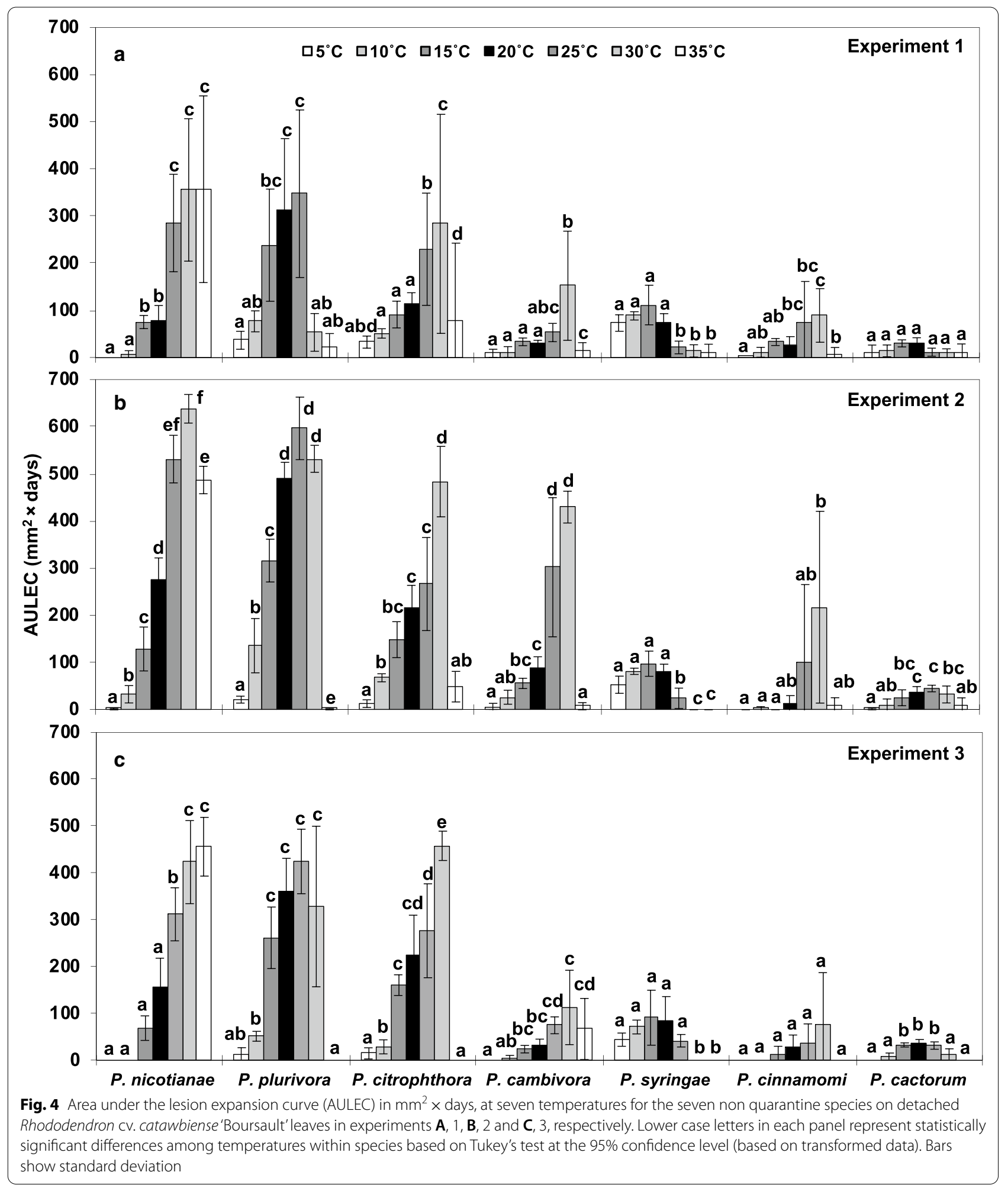

all three experiments $(P<0.05)$ except in experiment 1 where there was no significant difference between these three species and P. syringae $(P>0.05)$ (Fig. 4$)$. In all experiments $P$. syringae developed highest AULEC at $5{ }^{\circ} \mathrm{C}$ than any other species $(P<0.01)$. At $35{ }^{\circ} \mathrm{C} P$. nicotianae showed significantly higher AULEC in all 

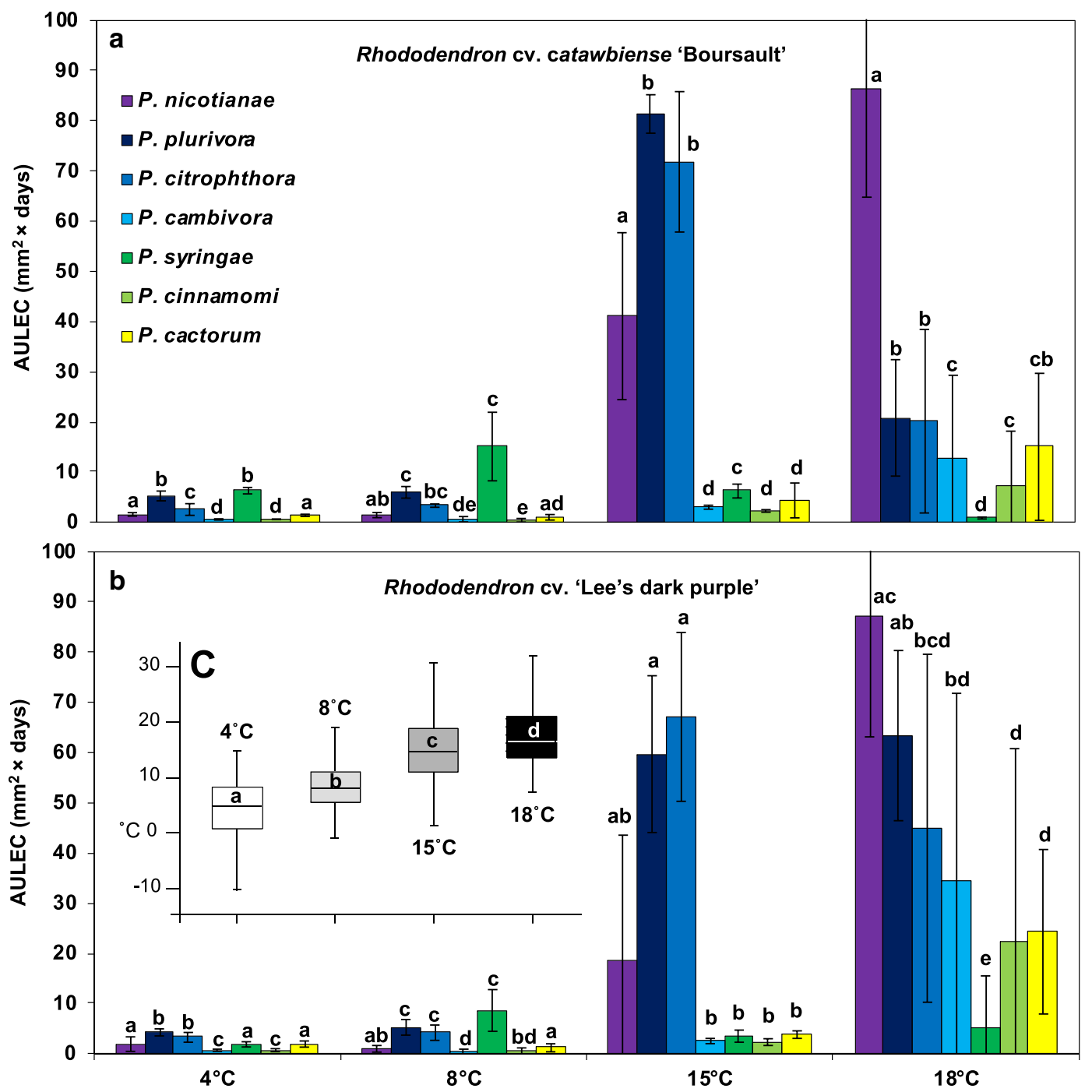

Fig. 5 Whole plant field inoculation of seven Phytophthora species on two Rhododendron cultivars using wound inoculation. Graphs show area under the lesion expansion curve (AULEC) in $\mathrm{mm}^{2} \times$ days for each Phytophthora spp. at each seasonally observed temperature (inset $\mathbf{C}$ ) of 4,8 , 15 , and $18^{\circ} \mathrm{C}$, on $\mathbf{A}$, Rhododendron cv. catawbiense 'Boursault', and $\mathbf{B}$, Rhododendron cv. 'Lee's dark purple'. Inset, $\mathbf{C}$, shows the temperatures ( ${ }^{\circ} \mathrm{C}$ ) measured during each of the four experiments. Bars show standard deviation, lower case letters represent statistically significant differences based on Tukey's test at the 95\% confidence level (based on transformed data)

experiments $(P<0.01)$. At both 15 and $20{ }^{\circ} \mathrm{C} P$. plurivora was the species with the highest AULEC in all experiments $(P<0.01)$.

\section{Aggressiveness and effect of temperature: field experiments}

Phytophthora aggressiveness on Rhododendron species was evaluated in four field studies with average observed temperatures of $4,8,15$, and $18{ }^{\circ} \mathrm{C}$ (Fig. $5 \mathrm{C}$, inset). In each of the four experiments there was a significant species by cultivar interaction $(P=0.041,0.038$, and $<0.001)$ (Table 3$)$. Results were similar in nature to detached leaf inoculations and radial growth assays in Petri dish culture (Fig. 3, 4). On Rhododendron cv. catawbiense 'Boursault', $P$. nicotianae had significantly higher AULEC than all the other species in experiment 1 (ca. $18{ }^{\circ} \mathrm{C}$ ) (Fig. 5, A). On Rhododendron cv. 'Lee's dark purple' P. nicotianae had significantly higher AULEC than all species except P. citrophthora in experiment 1 (ca. $18{ }^{\circ} \mathrm{C}$ ) (Fig. 5B). $P$. plurivora and $P$. citrophthora were the most aggressive species in experiment 2 (ca. $15^{\circ} \mathrm{C}$ ) (Fig. 5A, B). On Rhododendron $\mathrm{Cv}$. catawbiense 'Boursault' $P$. plurivora and P. citrophthora had significantly higher AULEC than any other species (Fig. 5A). On Rhododendron cv. 'Lee's dark 
Table 3 Analysis of variance of AULEC from whole plant field inoculation of seven Phytophthora spp. on two Rhododendron cultivars

\begin{tabular}{|c|c|c|c|c|}
\hline Experiment & Source & DF & $F$ & $P$ \\
\hline \multirow[t]{5}{*}{$1\left(18^{\circ} \mathrm{C}\right)$} & Species & 6 & 58.81 & $<0.001$ \\
\hline & Cultivar & 1 & 38.20 & $<0.001$ \\
\hline & Species*Cultivar & 6 & 2.81 & 0.012 \\
\hline & Block & 5 & 2.91 & 0.060 \\
\hline & Leaf(Block) & 12 & 0.71 & 0.737 \\
\hline \multirow[t]{3}{*}{$\mathrm{CB}$} & Species & 6 & 39.24 & $<0.001$ \\
\hline & Block & 5 & 5.86 & 0.006 \\
\hline & Leaf(Block) & 12 & 0.36 & 0.975 \\
\hline \multirow[t]{3}{*}{ LDP } & Species & 6 & 23.92 & $<0.001$ \\
\hline & Block & 5 & 1.97 & 0.156 \\
\hline & Leaf(Block) & 12 & 0.74 & 0.705 \\
\hline \multirow[t]{5}{*}{$2\left(15^{\circ} \mathrm{C}\right)$} & Species & 6 & 125.12 & $<0.001$ \\
\hline & Cultivar & 1 & 18.92 & $<0.001$ \\
\hline & Species*Cultivar & 6 & 3.54 & 0.002 \\
\hline & Block & 5 & 0.39 & 0.845 \\
\hline & Leaf(Block) & 12 & 1.15 & 0.322 \\
\hline \multirow[t]{3}{*}{$\mathrm{CB}$} & Species & 6 & 183.79 & $<0.001$ \\
\hline & Block & 5 & 0.75 & 0.600 \\
\hline & Leaf(Block) & 12 & 0.98 & 0.472 \\
\hline \multirow[t]{3}{*}{ LDP } & Species & 6 & 31.63 & $<0.001$ \\
\hline & Block & 5 & 0.27 & 0.922 \\
\hline & Leaf(Block) & 12 & 0.65 & 0.799 \\
\hline \multirow[t]{5}{*}{$3\left(4^{\circ} \mathrm{C}\right)$} & Species & 6 & 130.58 & $<0.001$ \\
\hline & Cultivar & 1 & 4.85 & 0.029 \\
\hline & Species*Cultivar & 6 & 14.68 & $<0.001$ \\
\hline & Block & 5 & 6.01 & 0.005 \\
\hline & Leaf(Block) & 12 & 0.53 & 0.892 \\
\hline \multirow[t]{3}{*}{$C B$} & Species & 6 & 120.04 & $<0.001$ \\
\hline & Block & 5 & $2 . .92$ & 0.059 \\
\hline & Leaf(Block) & 12 & 0.26 & 0.994 \\
\hline \multirow[t]{3}{*}{ LDP } & Species & 6 & 45.37 & $<0.001$ \\
\hline & Block & 5 & 7.37 & 0.002 \\
\hline & Leaf(Block) & 12 & 0.60 & 0.834 \\
\hline \multirow[t]{5}{*}{$4\left(8^{\circ} \mathrm{C}\right)$} & Species & 6 & 53.66 & $<0.001$ \\
\hline & Cultivar & 1 & 4.41 & 0.037 \\
\hline & Species*Cultivar & 6 & 1.67 & 0.130 \\
\hline & Block & 5 & 41.49 & $<0.001$ \\
\hline & Leaf(Block) & 12 & 0.13 & 1.000 \\
\hline \multirow[t]{3}{*}{$C B$} & Species & 6 & 30.45 & $<0.001$ \\
\hline & Block & 5 & 12.50 & $<0.001$ \\
\hline & Leaf(Block) & 12 & 0.42 & 0.951 \\
\hline \multirow[t]{3}{*}{ LDP } & Species & 6 & 25.34 & $<0.001$ \\
\hline & Block & 5 & 16.77 & $<0.001$ \\
\hline & Leaf(Block) & 12 & 0.15 & 1.000 \\
\hline
\end{tabular}

Analysis of variance of AULEC ( $\mathrm{mm}^{2} \times$ days) (square root transformed). $\mathrm{CB}=$ Rhododendron $\mathrm{cv}$. catawbiense 'Boursault'; $\mathrm{LDP}=$ Rhododendron $\mathrm{cv}$. catawbiense $\times$ unknown 'Lee's dark purple'. Bold $P$ values are significant at $<0.05$ purple' there was no significant difference between these two species and P. nicotianae (Fig. 5B). P. syringae was more aggressive at moderate temperatures and caused most disease in experiment 4 (ca. $8{ }^{\circ} \mathrm{C}$ ) (Fig. 5). There was no significant difference between $P$. syringae and $P$. plurivora and $P$. citrophthora at $8{ }^{\circ} \mathrm{C}$ on either cultivar (Fig. 5A, B). In experiment $3\left(\right.$ ca. $\left.4{ }^{\circ} \mathrm{C}\right)$ P. syringae and $P$. plurivora had the highest AULEC on Rhododendron cv. catawbiense 'Boursault' (Fig. 5A). However, on Rhododendron cv. 'Lee's dark purple' P. plurivora and P. citrophthora developed the highest AULEC (Fig. 5B).

\section{Discussion}

Our work revealed some interesting results regarding aggressiveness and temperature responses among Phytophthora spp. P. nicotianae was consistently able to grow at higher temperatures $\left(\geq 35{ }^{\circ} \mathrm{C}\right)$ than any of the other Phytophthora spp. P. nicotianae showed significantly higher aggressiveness (in terms of AULEC) than any of the other species when studied at ca. $18{ }^{\circ} \mathrm{C}$ in experiment 1 in the field and at $35^{\circ} \mathrm{C}$ in the growth chamber. The ability of $P$. nicotianae to grow at high temperatures has been used as a diagnostic characteristic to identify this species relative to other Phytophthora spp. as developed by Tucker (1931). Across experiments, P. cactorum, $P$. cambivora, $P$. citrophthora, and $P$. plurivora generally prefer higher temperatures $\left(25-30^{\circ} \mathrm{C}\right)$. In contrast, $P$. kernoviae, $P$. nemorosa and $P$. syringae preferred lower temperature regimes $\left(<25^{\circ} \mathrm{C}\right)$.

P. cinnamomi and P. cactorum, typically thought of as root-infecting species, were able to cause as much foliar disease (lesion area or AULEC) as $P$. syringae (a foliar pathogen) with non-wound inoculated under field conditions (Fig. 5) as well as with wound inoculations indicating that these pathogens might be able to cause lesions under field conditions. It should be noted that the inoculation techniques used here may have facilitated infection of plants or plant parts that would not naturally get infected. We deliberately created an environment conducive to infection and disease development to facilitate the study of the epidemiology of these twelve species. In wound inoculating in this way we may have observed more disease than would naturally occur. Due to the challenging nature of working with multiple Phytophthora species it was necessary to conduct some experiments with wounding as an inoculation technique to reduce the likelihood of inoculation failure. With non-wounded inoculations there can be considerably greater variation in the data due to higher failure rates of inoculation. It is generally accepted that non-wounded inoculation methods more closely reflect the natural infection process, but in the nurseries plants may get damaged by tipping over 
or being overcrowded and these wounds may provide the opportunity for infection to occur.

$P$. lateralis is rarely isolated from nurseries in Oregon and when it is, it is usually from soil substrate rather than from infected plants (Parke et al. 2014; Knaus et al. 2015; Prospero et al. 2013; Junker et al. 2016). It has only once been reported on Rhododendron (Hoitink and Schmitthenner 1974) and is considered to have a narrow host range including Port Orford cedar and Pacific yew (Erwin and Ribeiro 1996). Here we observed disease development on Rhododendron in both wounded and nonwounded inoculations.

P. syringae stood out as it appeared to be a relatively weak pathogen, showing no sporulation and low levels of disease severity, except at low temperatures. In Oregon it was among the species isolated most frequently from different nursery crops, mostly Rhododendron, Viburnum, Pieris, and Kalmia spp., after P. plurivora and P. cinnamomi (Grünwald et al. 2011; Parke et al. 2014). Thus, our results might indicate that $P$. syringae, although not an aggressive pathogen in warmer climates, is well adapted to the cool climate of the Pacific Northwest. Temperatures in the Pacific Northwest typically average between 9 and $11{ }^{\circ} \mathrm{C}$ annually, with an average high of $16^{\circ} \mathrm{C}$ and low of $5{ }^{\circ} \mathrm{C}$ (Mote 2003).

During the fourth field experiment, when the mean temperature was $8{ }^{\circ} \mathrm{C}, P$. syringae infection spread to other leaves on the inoculated plants. This type of spread was not observed with any of the other species or in any other season. Usually, the inoculated leaf developed a second lesion at the tip where water pooled and dripped from the leaf, and frequently lesions developed on leaves below the inoculated leaf. Leaves above and adjacent to the inoculated leaf were also seen to develop secondary lesions. This type of spread of $P$. syringae was observed in both 2009 and 2010 during springtime in Oregon. The ability of $P$. syringae to spread quickly at lower temperatures further supports our inference that $P$. syringae is adapted to the climate of the Pacific Northwest.

P. nicotianae was the only other species we observed spreading beyond the inoculated leaf during the field experiments. Direct spread was observed as lesions to the stem and adjacent leaves. This type of spread was only seen during the field experiments carried out in experiments 2 and 1 at observed mean temperatures of 15 and $18^{\circ} \mathrm{C}$, respectively. Considering how problematic Phytophthora spp. are in the nursery industry it is surprising that disease spread was so rarely observed in our field experiments. By spacing out the inoculated plants in the field experiment to avoid cross contamination of treatments, the plant canopy is broken up and this may have altered the microenvironment sufficiently to reduce sporulation and the potential for infection.
P. kernoviae should be of particular concern to regulatory agencies. In our studies, P. kernoviae was consistently among the most aggressive Phytophthora species (with large lesion area and high AULEC) with the highest sporulation. This is of note due to the threat P. kernoviae could pose to the nursery and forestry industries in the USA if it were introduced (Brasier et al. 2005). This species causes bark necrosis and bleeding cankers of European beech (Fagus sylvatica) and foliar necrosis and shoot dieback of Rhododendron ponticum in the woodland of Cornwall, UK and has been found in the nursery industry in the UK (Brasier et al. 2005). It is thought that the spread of $P$. ramorum and $P$. kernoviae is in part due to their ability to sporulate on asymptomatic plants (Denman et al. 2009).

Further studies on infection efficiency and sporulation at different temperatures would provide more valuable insights into the potential threat of these species for disease development at different times of the year. In this paper, sporulation and infection efficiency were assessed at $18{ }^{\circ} \mathrm{C}$ only. This was due to containment constraints and the availability of growth chamber space for different temperatures. Producing sufficient quantities of zoospore inoculum simultaneously makes non wounded inoculations challenging. It is likely that the species which did not sporulate in these experiments may do so at different temperatures, such as $P$. syringae which is favored by lower temperatures.

Our work also does not inform on variability among isolates within species across all experiments. The temperature experiment on detached leaves was only conducted with one isolate per taxon (Table1). In other experiments a mixture of isolates was used due to the complexity of the experiments. Similarly, we only included strains of the NA1 clonal lineages of P. ramorum. Hence, no inferences can be made across all variants within species.

The field experiments were conducted at different times of the year and this not only altered the mean temperatures of those experiments, but it also affected the quantity and types of precipitation experienced by the Rhododendron plants. These effects were to some extent controlled for by the application of overhead irrigation during the drier experiments; however, these precipitation differences will likely have an effect on the lifecycle of the Phytophthora species inoculated. There is also a seasonal effect on the susceptibility of Rhododendron as these evergreen plants go dormant in the winter, their leaves develop a thicker waxy layer enabling them to withstand the colder weather (Meyer 1928). This may confer resistance to infection by Phytophthora spp. as well as cold resistance. This increased resistance to infection was observed during whole plant dip and detached 
leaf inoculation experiments where we found that infection rates dropped around October each year (data not shown). This limited our ability to conduct non-wounded inoculations during the winter months even using greenhouse grown plants.

Few studies have compared the severity of multiple Phytophthora spp. on a single host (Jeger and Pautasso 2008; Wilcox and Mircetich 1985). This might be because working simultaneously with several Phytophthora species provides unique challenges. One major challenge is the difficulty of producing sporangial or zoospore inoculum for all taxa, appropriately timed for inoculation on a given date (Ahonsi et al. 2007; Erwin and Ribeiro 1996). Another challenge is capturing variation within a species, which can be accomplished by using several isolates per species. This obviously increases the logistical constraints. Brasier and Kirk (2001) compared the aggressiveness of several variants of alder Phytophthoras alongside 7 other species: P. cambivora, P. cinnamomi, $P$. citricola, $P$. cryptogea, $P$. fragariae var. rubi, $P$. gonapodyides, and $P$. megasperma. Their study consisted of wounded inoculation of logs using agar plugs and aggressiveness was assessed by measuring lesion area. This hybrid alder Phytophthora was found to be relatively host specific and more aggressive on alder when compared with $P$. cambivora, and it has since been described as $P$. alni (Brasier et al. 2004).

We are only aware of one study contrasting different Phytophthora species on Rhododendron. Linderman et al. (2006) contrasted $P$. ramorum with $P$. cactorum, $P$. cinnamomi, $P$. citricola, $P$. citrophthora, $P$. heveae, $P$. nicotianae and $P$. syringae using detached leaf, wound-inoculations on Rhododendron cv. 'Nova Zembla'. Their results are based on a single experiment that showed that $P$. cactorum, $P$. citricola, $P$. citrophthora and $P$. nicotianae were most pathogenic at $20{ }^{\circ} \mathrm{C}$. The work was not validated with whole plant assays and non-wounded inoculations. $P$. syringae again caused very little disease at these temperatures. Our experiments also indicated the same four species were among the most aggressive and we found $P$. syringae was less aggressive at higher temperatures of $20^{\circ} \mathrm{C}$ and above. Interactions between Phytophthora species and host cultivars and between temperatures and Phytophthora species make it difficult to rank the pathogens in terms of aggressiveness.

A greater understanding of the differences among species and the ability to identify Phytophthoras to species level using PCR and sequencing means that control of Phytophthora spp. in nurseries can be better targeted towards a particular species. For example, if P. syringae is known to be present in a nursery, management practices need to be focused on the colder months. Control against the spread of Phytophthora species which sporulate prolifically should place emphasis on drainage and irrigation management. Management of a foliar epidemic should focus on breaking up the plant canopy by spacing out the plants to alter the microenvironment. The ability for Phytophthora spp. to spread in soil or on asymptomatic plants as document for $P$. kernoviae and $P$. ramorum (Denman et al. 2009) means that visual inspection of plants prior to import or export is not sufficient to reduce the risk of introducing novel pathogens to the nursery industry or to new environments. These results further our understanding of the epidemiology of these important Phytophthora species and add to the body of information that will aid the development of best management strategies to manage Phytophthora diseases in nurseries and mitigate the spread of Phytophthora species to new ecosystems (Parke and Grünwald 2012).

\section{Acknowledgements}

We are grateful to Everett Hansen and Chris Mundt for providing comments on an earlier draft of this manuscript. We thank Karan Fairchild, Kim Henslee, Val Fieland, and Caroline Press for excellent technical support. Mention of trade names or commercial products in this manuscript are solely for the purpose of providing specific information and do not imply recommendation or endorsement.

\section{Authors' contributions}

$\mathrm{CT}$ and NG contributed to the analysis and interpretation of the data and writing of the manuscript; CT conducted all experimental work. NG obtained funding. Both authors read and approved the final manuscript.

\section{Funding}

This work was supported in part by funds from USDA ARS CRIS Project 2072 22000-041-00-D, the USDA ARS North West Nursery Research Initiative, the USDA ARS Floriculture Nursery Research Initiative, and the Oregon Department of Agriculture-Oregon Association of Nurseries research program.

\section{Availability of data and materials}

Data are available at the following repository: https://github.com/grunw aldlab/Phytophthora_epidemiology_on_Rhododendron.

\section{Declarations}

Ethics approval and consent to participate Not applicable.

\section{Consent for publication}

Both authors and their institutions agree to publication.

\section{Competing interests}

The authors declare that they have no competing interests.

\section{Author details}

${ }^{1}$ Department of Botany and Plant Pathology, Oregon State University, Corvallis, OR 97331, USA. ${ }^{2}$ Horticultural Crops Research Laboratory, USDA ARS, Corvallis, OR 97330, USA.

Received: 19 March 2021 Accepted: 18 June 2021

Published online: 30 June 2021

\section{References}

Ahonsi MO, Banko TJ, Hong C. A simple in-vitro 'wet-plate' method for mass production of Phytophthora nicotianae zoospores and factors influencing zoospore production. J Microbiol Methods. 2007;70:557-60. 
Barwell L, Perez-Sierra A, Henricot B, Harris A, Burgess TI, Hardy G et al. Evolutionary trait-based approaches for predicting future global impacts of plant pathogens in the genus Phytophthora ed Luke Florey. J Appl Ecol. 2021; 58:718-730.

Brasier CM. The biosecurity threat to the UK and global environment from international trade in plants. Plant Pathol. 2008;57:792-808.

Brasier CM, Kirk SA. Comparative aggressiveness of standard and variant hybrid alder phytophthoras, Phytophthora cambivora and other Phytophthora species on bark of Alnus, Quercus and other woody hosts. Plant Pathol. 2001;50:218-29.

Brasier C, Webber J. Plant pathology: Sudden larch death. Nature. 2010;466:824-5.

Brasier CM, Kirk SA, Delcan J, Cooke DEL, Jung T, Man In't Veld, W. A. . Phytophthora alni sp. nov. and its variants: designation of emerging heteroploid hybrid pathogens spreading on Alnus trees. Mycol Res. 2004;108:1172-84.

Brasier CM, Beales PA, Kirk SA, Denman S, Rose J. Phytophthora kernoviae sp nov., an invasive pathogen causing bleeding stem lesions on forest trees and foliar necrosis of ornamentals in the UK. Mycol Res. 2005;109:853-9.

Denman S, Kirk SA, Moralejo E, Webber JF. Phytophthora ramorum and Phytophthora kernoviae on naturally infected asymptomatic foliage. EPPO Bulletin. 2009;39:105-11.

Erwin DC, Ribeiro OK. Phytophthora Diseases Worldwide. St. Paul, Minn.: APS Press; 1996

Fry W. Phytophthora infestans: the plant (and R gene) destroyer. Mol Plant Pathol. 2008;9:385-402.

Fry WE, Birch PRJ, Judelson HS, Grünwald NJ, Danies G, Everts KL, et al. Five reasons to consider Phytophthora infestans a reemerging pathogen. Phytopathology. 2015;105:966-81.

Goss EM, Larsen M, Chastagner GA, Givens DR, Grünwald NJ. Population genetic analysis infers migration pathways of Phytophthora ramorum in US nurseries. PLoS Pathogens. 2009;5:e1000583.

Goss EM, Larsen M, Vercauteren A, Werres S, Heungens K, Grünwald NJ. Phytophthora ramorum in Canada: Evidence for migration within North America and from Europe. Phytopathology. 2011;101:166-71.

Grünwald NJ, Goss EM, Press CM. Phytophthora ramorum: a pathogen with a remarkably wide host range causing sudden oak death on oaks and ramorum blight on woody ornamentals. Mol Plant Pathol. 2008;9:729-40.

Grünwald NJ, Martin FN, Larsen MM, Sullivan CM, Press CM, Coffey MD, et al. Phytophthora-ID.org: a sequence-based Phytophthora identification tool. Plant Dis. 2011;95:337-42.

Grünwald NJ, Garbelotto M, Goss EM, Heungens K, Prospero S. Emergence of the sudden oak death pathogen Phytophthora ramorum. Trends Microbiol. 2012;20:131-8.

Hardham AR. Phytophthora cinnamomi. Mol Plant Pathol. 2005;6:589-604.

Harris AR, Brasier CM, Scanu B, Webber JF. Fitness characteristics of the European lineages of Phytophthora ramorum. Plant Pathol. 2021;70:275-86.

Hoitink HAJ, Schmitthenner AF. Relative prevalence and virulence of Phytophthora species involved in Rhododendron root rot. Phytopathology. 1974;64:1371-4.

Jeger MJ, Pautasso M. Comparative epidemiology of zoosporic plant pathogens. Eur J Plant Pathol. 2008;122:111-26.

Jones RK, Benson DM. Diseases of Woody Ornamentals and Trees in Nurseries. St. Paul, Minn: Amer Phytopathological Society; 2001

Jung, T., Orlikowski, L., Henricot, B., Abad-Campos, P., Aday, A. G., Aguín Casal, O., et al. 2016. Widespread Phytophthora infestations in European nurseries put forest, semi-natural and horticultural ecosystems at high risk of Phytophthora diseases ed. M.-L. Deprez-Loustau. For. Path. 46:134-163.

Junker C, Goff P, Wagner S, Werres S. Occurrence of Phytophthora species in commercial nursery production. Plant Health Progress. 2016;17:64-75.

Kato M, Mizubuti ES, Goodwin SB, Fry WE. Sensitivity to protectant fungicides and pathogenic fitness of clonal lineages of Phytophthora infestans in the United States. Phytopathology. 1997;87:973-8.

Knaus BJ, Fieland VJ, Graham KA, Grünwald NJ. Diversity of foliar Phytophthora species on Rhododendron in Oregon nurseries. Plant Dis. 2015;99:1326-32.

Lebreton L, Lucas JM, Andrivon D. Aggressiveness and competitive fitness of Phytophthora infestans isolates collected from potato and tomato in France. Phytopathology. 1999;89(8):679-86. https://doi.org/10.1094/ PHYTO.1999.89.8.679.
Liebhold AM, Brockerhoff EG, Garrett L, Parke JL, Britton KO. Live plant imports: the major pathway for forest insect and pathogen invasions of the US. Front Ecol Environ. 2012;10:135-43.

Linderman RG, Davis EA, Marlow JL. Response of selected nursery crop plants to inoculation with isolates of Phytophthora ramorum and other Phytophthora species. HortTech. 2006;16:216-24.

Mascheretti S, Croucher PJP, Vettraino A, Prospero S, Garbelotto M. Reconstruction of the sudden oak death epidemic in California through microsatellite analysis of the pathogen Phytophthora ramorum. Mol Ecol. 2008; 17:2755-68

Meyer BS. Seasonal variations in the physical and chemical properties of the leaves of the pitch pine, with especial reference to cold resistance. Am J Bot. 1928;15:449-72.

Mote PW. Trends in temperature and precipitation in the Pacific Northwest during the twentieth century. Northwest Sci. 2003;77:271-328.

Parke JL, Grünwald NJ. A systems approach for management of pests and pathogens of nursery crops. Plant Dis. 2012;96:1236-44.

Parke J, Knaus BJ, Fieland VJ, Lewis C, Grünwald NJ. Phytophthora community structure analyses in Oregon nurseries inform systems approaches to disease management. Phytopathology. 2014;99:1326-32.

Prospero S, Vercauteren A, Heungens K, Belbahri L, Rigling D. Phytophthora diversity and the population structure of Phytophthora ramorum in Swiss ornamental nurseries. Plant Pathol. 2013;62:1063-71.

Scott P, Bader MK-F, Burgess T, Hardy G, Williams N. Global biogeography and invasion risk of the plant pathogen genus Phytophthora. Environ Sci Policy. 2019;101:175-82.

Sparks A, Esker P, Bates M, Dall'Acqua W, Guo Z, Segovia V, et al. 2008. Ecology and Epidemiology in R: Disease Progress over Time. Plant Health Instructor.

Spielman LJ, MCMASTER BJ, Fry WE. Relationships among measurements of fitness and disease severity in Phytophthora infestans. Plant Pathol. 1992;41(3):317-324. https://doi.org/10.1111/j.1365-3059.1992.tb02353.x.

Tooley P, Sweigard J, Fry W. Fitness and virulence of Phytophthora infestans isolates from sexual and asexual populations. Phytopathology. 1986;76:1209-12.

Tucker CM. Taxonomy of the genus Phytophthora de Bary. University of Missouri Agricultural Experiment Station, Research Bulletin; 1931. Vol. 153.

Tukey JW. The philosophy of multiple comparisons. Stat Sci. 1991;6:100-16.

Van Poucke K, Franceschini S, Webber JF, Vercauteren A, Turner JA, McCracken $A R$, et al. Discovery of a fourth evolutionary lineage of Phytophthora ramorum: EU2. Fungal Biol. 2012;116:1178-91.

Werres S, Marwitz R, Veld W, De Cock A, Bonants PJM, De Weerdt M, et al. Phytophthora ramorum sp nov., a new pathogen on Rhododendron and Viburnum. Mycol Res. 2001;105:1155-65.

Wilcox WF, Mircetich SM. Pathogenicity and relative virulence of seven Phytophthora spp. on Mahaleb and Mazzard cherry. Phytopathology. 1985;75:221.

\section{Publisher's Note}

Springer Nature remains neutral with regard to jurisdictional claims in published maps and institutional affiliations.

Ready to submit your research? Choose BMC and benefit from:

- fast, convenient online submission

- thorough peer review by experienced researchers in your field

- rapid publication on acceptance

- support for research data, including large and complex data types

- gold Open Access which fosters wider collaboration and increased citations

- maximum visibility for your research: over 100M website views per year

At BMC, research is always in progress.

Learn more biomedcentral.com/submissions 